\title{
HUBUNGAN MAKANAN PENDAMPING ASI DINI DENGAN INSIDEN DIARE PADA BAYI 0-6 BULAN DI PUSKESMAS STABAT
}

\author{
Arnof Yerni \\ STIkes Putra Abadi Langkat Stabat \\ Email: arnofy@yahoo.com
}

\begin{abstract}
Weaning food for breastfeeding babies should always be given at the appropriate time, meaning that all babies should start get weaning food from age six months old and counting. The research was done in Puskesmas Stabat (Stabat Community Health Center), Stabat District, Langkat Regency, from December 2016 to February 2017. Theobjective of this research is to assess the correlation of early weaning food giving and diarrhea incidence in $0-6$ months babies. This research used a descriptive correlation study design. The population of the research is all mothers with $0-6$ months old babies in Puskesmas Stabat numbering 389 people. The sample of the research is 40 people, or $10 \%$ of the population, using accidental sampling technique. The independent variable is early weaning food giving to $0-6$ months old babies, and the dependent variable being diarrhea incidence. The data was collected using questionnaires and interviews, then analyzed using chi squaretest (CI 95\% and $\alpha=0,05)$. The statistical test showed the correlation of early weaning food giving and diarrhea incidence in 0-6 months old babies ( $p$-value $=0,001)$ as $p<0,05$ which means there is a significant correlation between early weaning food with diarrhea incidence. The conclusion of the research is that early weaning food giving influences diarrhea incidence in $0-6$ months old babies at Puskesmas Stabat.
\end{abstract}

Keywords: MP ASI, infant 0-6 months, diarrhea

\section{PENDAHULUAN}

Diare masih merupakan masalah kesehatan masyarakat di Indonesia. Menurut profil kesehatan Indonesia tahun 2016, diare merupakan penyakit endemis dan merupakan potensial kejadian luar biasa yang sering disertai kematian. Diare menjadi kejadian buang air besar dengan konsistensi lebih cair dari biasanya, dengan frekuensi tiga kali atau lebih dalam periode 24 jam (Suharyono, 2015).

Diare dapat menyebabkan cairan tubuh terkuras keluar melalui tinja. Bila penderita diare banyak sekali kehilangan cairan tubuh maka hal ini dapat menyebabkan kematian terutama pada bayi dan anak-anak usia di bawah lima tahun (Tamimi, Jurnalis, \& Sulastri, 2016). Dampak negatif penyakit diare pada bayi dan anak-anak antara lain adalah menghambat proses tumbuh kembang anak yang pada akhirnya dapat menurunkan kualitas hidup anak. Penyakit diare di masyarakat lebih dikenal dengan istilah "Muntaber". Penyakit ini menimpa pada bayi dan tidak segera diobati dalam waktu singkat ( \pm 48 jam) akan menyebabkan kematian (Arianni, 2016). 
Orang tua berperan besar dalam menentukan penyebab anak terkena diare. Bayi dan balita yang masih menyusui dengan ASI eksklusif umumnya jarang diare karena tidak terkontaminasi dari luar. Namun, susu formula dan makanan pendamping ASI dapat terkontaminasi bakteri dan virus (Fikawati, 2015). Kematian bayi di Indonesia sangat tinggi.Bahkan di seluruh dunia, Indonesia menduduki rangking keenam dengan angka kejadian sekitar 6 juta bayi yang mati pertahunnya. Kasus kematian bayi di Indonesia ini, menurut Masri (2014), kematian bayi di Indonesia disebabkan oleh penyakit diare. Cara untuk mendiagnosis diare, maka pemeriksaan antigen secara langsung dari tinja mempunyai nilai sensitifitas cukup tinggi (70-90\%), tetapi biaya pemeriksaan cukup mahal (Arianni, 2016).

Pemberian makan sebelum bayi berumur 6 bulan tidak dapat memberikan perlindungan yang besar pada bayi dari berbagai penyakit.Hal ini disebabkan sistem imun bayi berumur kurang dari 6 bulan belum sempurna. Pemberian makanan pendamping ASI (MPASI) dini sama saja dengan membuka pintu gerbang masuknya berbagai jenis kuman. Belum lagi jika tidak disajikan secara higienis. Hasil riset terakhir dari peneliti di Indonesia menunjukkan bahwa bayi yang mendapatkan MPASI sebelum bayi berumur 6 bulan, lebih banyak terserang diare, sembelit, batuk-pilek, dan panas dibandingkan bayi yang hanya mendapat ASI eksklusif (Amin, 2015). Makanan pendamping ASI harus diberikan tepat pada waktunya, artinya bahwa semua bayi harus mulai mendapatkan makanan sebagai tambahan ASI dari umur 6 bulan kedepan. Makanan harus diberikan secara adekuat, yang berarti bahwa nilai nutrisi dari makanan pendamping ASI harus sama dengan ASI. Makanan harus dipersiapkan dan diberikan dengan cara yang aman, harus dipastikan memiliki resiko sekecil mungkin dari kontaminasi patogen. Makanan harus diberikan dengan cara layak secara tekstur dan jumlah yang cukup (Suryono, 2014).

Menurut penelitian terdahulu pada 900 ibu di Jabotabek diperoleh fakta bahwa hanya sekitar 5\% ibu yang memberikan ASI Eksklusif jpada bayinya, sedangkan sekitar $98 \%$ ibu lainnya sudah memberikan Makanan Pendamping ASI (MPASI) pada bayi mereka ketika bayi masih berumur 1 bulan. Adapun jenis dan bentuk MPASI yang diberikan adalah pisang dan nasi lembek, padahal MPASI baru dapat diperkenalkan pada bayi setelah bayi tersebut berumur 6 bulan. Hal ini berakibat pada meningkatnya angka kesakitan pada bayi karena alat 
pencernaan bayi belum mampu untuk mencerna MPASI, sehingga menimbulkan masalah gizi, akibatnya pertumbuhan dan perkembangan bayi terganggu.

Data mengenai insiden diare dari Dinas Kesehatan Kabupaten Langkat pada tahun 2016 diketahui bahwa jumlah penderita diare semua umur sebanyak 5.132 jiwa yang tersebar di semua Puskesmas. Wilayah kerja Puskesmas dengan jumlah penduduk 25.855 di ketahui jumlah anak bayi 389 jiwa dengan angka insiden diare 96 jiwa. Penyebab masih adanya angka insiden diare pada anak disebabkan oleh beberapa faktor salah satu diantaranya adalah memberikan makanan pendamping ASI dini. Berdasarkan latar belakag di atas penulis tertarik untuk melakukan penelitian untuk mengetahui hubungan antara pemberian makanan pendamping ASI dini dengan insiden diare, khususnya pada anak usia 0-6 bulan di Puskesmas Stabat Kecamatan Stabat Kabupaten Langkat tahun 2017.

Tujuan penelitian ini untuk mengetahui apakah ada hubungan antara pemberian makanan pendamping ASI dini dengan insiden diare pada bayi 0-6 bulan di Puskesmas Stabat, Kecamatan Langkat tahun 2017.

\section{METODE}

Desain penelitian yang digunakan studi deskriptif korelasi. Variabel- variabel yang diidentifikasi adalah hubungan pemberian makanan pendamping ASI dini dengan insiden diare pada bayi 0-6 bulan. Penelitian dilakukan di Puskesmas Stabat, Kecamatan Stabat Kabupaten Langkat. Penelitian dilakukan pada bulan Desember hingga bulan Februari 2017.

Populasi dalam penelitian ini adalah adalah ibu yang mempunyai bayi usia 0 6 bulan yang memberikan makanan pendamping ASI yang berjumlah 389 orang. Metode pengambilan sampel yang digunakan adalah accidental sampling dan memenuhi kriteria sampel yang telah ditentukan kriteria inklusi (Notoatmodjo, 2012) yaitu ibu yang memberikan makanan pendamping ASI pada bayi usia 0-6 bulan

Pengumpulan data menggunakan kuesioner dan wawancara. Dalam penelitian ini data dikumpulkan menggunakan kuesioner dan wawancara. Data yang telah terkumpul diolah secara manual meliputi pengisian hasil wawancara dan memberikan skor pada lembar kuesioner kemudian dilakukan penggolahan data. Pengolahan data dilakukan dengan menggunakan uji Chi Square untuk menentukan apakah terdapat hubungan yang signifikan antara kedua variabel, maka dilakukan pengamatan terhadap nilai signifikansi $(p)$ pada hasil analisa $p<$ 0,05 . 


\section{HASIL DAN PEMBAHASAN}

Tabel 1. Distribusi Frekuensi Identitas Ibu yang Mempunyai Bayi 0-6 Bulan di Puskesmas Stabat Kecamatan Stabat Kabupaten Langkat

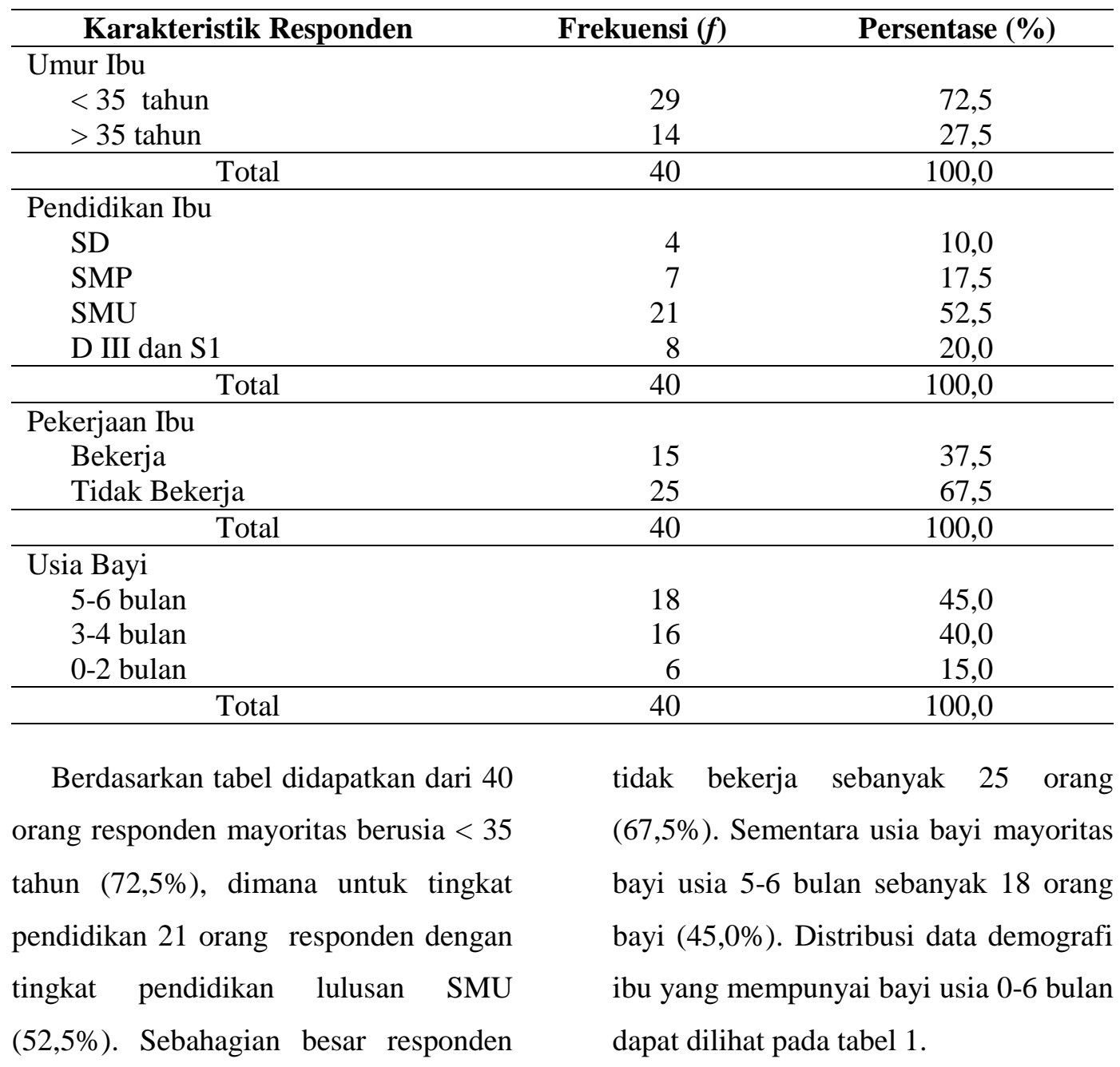
bekerja sebagai ibu rumah tangga atau

Tabel 2. Distribusi Frekuensi Pemberian Makanan Pendamping ASI Dini di Puskesmas Stabat Kecamatan Stabat Kabupaten Langkat

\begin{tabular}{lcc}
\hline $\begin{array}{c}\text { Pemberian Makanan } \\
\text { Pendamping ASI }\end{array}$ & Frekuensi $(\boldsymbol{f})$ & Persentase (\%) \\
\hline Usia 5-6 bulan & 10 & 25 \\
Usia 3-4 bulan & 14 & 35 \\
Usia 0-2 bulan & 6 & 15 \\
Tidak Pernah & 10 & 25 \\
\hline \multicolumn{2}{c}{ Total } & 40 \\
\hline \multirow{2}{*}{ Penelitian ini menggambarkan } & 4 bulan sebanyak 14 orang (35\%), usia \\
tentang tingkatan usia pemberian & 5-6 bulan sebanyak 10 orang (25\%), dan \\
makanan pendamping ASI dini, dimana & 6 orang berusia 0-2 bulan (15\%), yang \\
mayoritas responden berada pada usia 3- & tidak pernah memberikan MP ASI dini
\end{tabular}


sebanyak 10 orang (25\%). Distribusi

pendamping ASI dini dapat dilihat pada frekuensi pemberian makanan tabel 2.

Tabel 3. Distribusi Frekuensi Insiden Diare Pada Bayi 0-6 Bulan di Puskesmas Stabat Kecamatan Stabat Kabupaten Langkat

\begin{tabular}{lcc}
\hline \multicolumn{1}{c}{ Insidensi Diare } & Frekuensi $(\boldsymbol{f})$ & Persentase $\mathbf{( \% )}$ \\
\hline Tidak Pernah mengalami diare & 10 & 25,0 \\
Pernah diare 1 kali & 17 & 42,5 \\
Pernah diare 2 kali & 9 & 22,5 \\
Pernah diare lebih dari 2 kali & 4 & 10,0 \\
\hline \multicolumn{1}{c}{ Total } & 40 & 100,0 \\
\hline
\end{tabular}

Hasil penelitian ini menunjukan bahwa 10 responden $(25,0 \%)$ dalam kategori tidak pernah mengalami diare, 30 orang responden $(75.0 \%)$ pernah mengalami diare, dimana 17 orang responden $(42,5 \%)$ pernah mengalami diare 1 kali,9 orang responden $(22,5 \%)$ pernah mengalami diare $2 \mathrm{kali}$, dan hanya 4 orang responden $(10,0 \%)$ pernah mengalami diare lebih dari 2 kali. Distribusi frekuensi insiden diare pada bayi $0-6$ bulan dapat dilihat pada tabel 3.

Tabel 4. Hubungan Antara Pemberian Makanan Pendamping ASI Dini dengan Insiden Diare pada Bayi 0-6 Bulan di Puskesmas Stabat Kecamatan Stabat Kabupaten Langkat

\begin{tabular}{|c|c|c|c|c|c|c|c|c|c|c|c|c|}
\hline \multirow{3}{*}{$\underset{\text { dini }}{\text { MP ASI }}$} & \multicolumn{10}{|c|}{ Variabel Diare } & \multirow{3}{*}{$\begin{array}{c}P \text { - } \\
\text { Value }\end{array}$} & \multirow{3}{*}{ OR } \\
\hline & \multicolumn{2}{|c|}{$\begin{array}{c}\text { Tidak } \\
\text { pernah }\end{array}$} & \multicolumn{2}{|c|}{$\begin{array}{c}\text { Pernah } 1 \\
\text { kali }\end{array}$} & \multicolumn{2}{|c|}{$\begin{array}{c}\text { Pernah } 2 \\
\text { kali }\end{array}$} & \multicolumn{2}{|c|}{$\begin{array}{c}\text { Pernah > } \\
2 \text { kali } \\
\end{array}$} & \multicolumn{2}{|c|}{ Total } & & \\
\hline & $f$ & $\%$ & $f$ & $\%$ & $f$ & $\%$ & $f$ & $\%$ & $\mathbf{N}$ & $\%$ & & \\
\hline $5-6$ bulan & 8 & 44,4 & 8 & 44,4 & 2 & 11,1 & 0 & 0 & 18 & 100 & 0.001 & 2.364 \\
\hline 3-4 bulan & 2 & 12,5 & 6 & 37,5 & 7 & 43,8 & 1 & 6,3 & 16 & 100 & & \\
\hline $0-2$ bulan & 0 & 0 & 3 & 50 & 0 & 0 & 3 & 50 & 6 & 100 & & \\
\hline Total & 10 & 25 & 17 & 42,5 & 9 & 22,5 & 4 & 10 & 40 & 100 & & \\
\hline
\end{tabular}

Hasil analisa berdasarkan penafsiran korelasi menurut uji Chi Square bahwa variabel hubungan antara pemberian makanan pendamping ASI dini dengan insiden diare memiliki hubungan positif, dengan nilai ( $p$ value 0,001$)$ jadi $p<$ 0,05 yang menunjukan bahwa hubungan kedua variabel tersebut signifikan atau ada hubungan antara pemberian MP ASI dini dengan insiden Diare.

\section{Pembahasan}

\section{Pemberian Makanan Pendamping ASI Dini}

Hasil penelitian didapatkan bahwa mayoritas bayi mendapatkan makanan pendamping ASI pada usia3-4 bulan (35\%). Hasil ini tidak sama dengan penelitian yang dilakukan oleh Maharani 
(2016) yang menyatakan bahwa dari 99 responden sebagian besar bayi sudah mendapat MPASI pada usia 1-3 bulan (25\%) bahkan ada yang sudah memberi MPASI begitu lahir. Pada penelitian tersebut pemberian MPASI pada usia 46 bulan terdapat pada $15 \%$ dari keseluruhan responden.

Makanan tambahan merupakan makanan untuk bayi selain ASI atau susu botol, sebagai penambah kekurangan ASI atau susu pengganti (PASI) (Fikawati, 2015). Pemberian makanan tambahan adalah memberi makanan lain selain ASI untuk mengisi kesenjangan antara kebutuhan nutrisi dengan jumlah yang didapat dari ASI (Amin, 2015).

MP-ASI diberikan mulai umur 6-24 bulan dan merupakan makanan peralihan dari ASI ke makanan keluarga.Pengenalan dan pemberian MP-ASI harus dilakukan secara bertahap baik bentuk maupun jumlah.Hal ini dimaksudkan untuk menyesuaikan kemampuan alat cerna bayi dalam menerima MP-ASI (DepKes, 2016).

Menurut DepKes (2016) pemberian makanan atau minuman pengganti ASI berbahaya bagi bayi karena saluran pencernaan bayi belum cukup kuat untuk mencernakan makanan atau minuman selain ASI.
Adapun waktu yang baik dalam memulai pemberian makanan tambahan pada bayi adalah umur 6 bulan.Makanan tambahan mulai diberikan umur enam bulan satu hari. Pada usia ini otot dan saraf didalam mulut bayi cukup berkembang untuk mengunyah, menggigit, menelan makanan dengan baik, mulai tumbuh gigi, suka memasukkan sesuatu ke dalam mulutnya dan berminat terhadap rasa yang baru (Fikawati, 2015). Menurut Tamimi et al. (2016) pemberian makanan tambahan pada bayi sebelum umur tersebut (>6 bulan) akan menimbulkan risiko sebagai berikut: 1) Anak akan minum ASI lebih sedikit dan ibu pun memproduksinya lebih sedikit sehingga akan lebih sulit untuk memenuhi kebutuhan nutrisi anak, 2) Anak mendapat faktor pelindung dari ASI lebih sedikit sehingga risiko infeksi meningkat, 3) Risiko diare juga meningkat karena makanan tambahan tidak sebersih ASI, 4) Makanan yang diberikan sebagai pengganti ASI sering encer, buburnya berkuah atau berupa sup karena mudah dimakan bayi, makanan ini memang membuat lambung penuh tetapi memberikan nutrient sedikit.

\section{Insidensi Diare Pada Bayi 0-6 Bulan}

Hasil penelitian menunjukan bahwa 26 responden (65\%) dalam kategori tidak pernah mengalami diare, 14 orang responden $(35 \%)$ pernah mengalami 
diare, dimana 10 orang responden (25\%) pernah mengalami diare 1 kali, 3 orang responden $(7,5 \%)$ pernah mengalami diare 2 kali, dan hanya 1 orang responden $(2,5 \%)$ pernah mengalami diare lebih dari 2 kali. Hasil penelitian ini sejalan dengan penelitian yang dilakukan oleh Tamimi et al. (2016) yang menyatakan bahwa kejadian diare yang dikategorikan berdasarkan frekuensi buang air besar (BAB) diperoleh bahwa persentase tertinggi sampel tidak mengalami diare dan lainnya mengalami kejadian diare.

Diare merupakan suatu penyakit dengan tanda-tanda adanya perubahan bentuk dan konsistensi tinja yang cair dan frekuensi buang air besar lebih dari 3 kali dalam sehari (Masri, 2014). Lebih jauh Masri menjelaskan bahwa diare merupakan mekanisme perlindungan tubuh untuk mengeluarkan sesuatu yang merugikan atau racun dari dalam tubuh. Namun, banyaknya cairan tubuh yang dikeluarkan bersama tinja akan mengakibatkan dehidrasi yang dapat berakibat kematian.

Menurut Maharani (2016), diare pada balita cukup berbahaya, karena dapat menimbul kan kematian bayi maupun balita serta angka kejadiannya cukup tinggi setiap tahunnya.Lima juta anak berusia kurang dari lima tahun meninggal setiap tahun akibat diare. Kejadian diare pada balita salah satunya disebabkan oleh higiene termasuk pengetahuan dan sikap ibu dalam pemberian makan, dimana bayi sudah diberi makanselain ASI (Air Susu Ibu) sebelum usia 6 bulan.

Hubungan Antara Pemberian Makanan Pendamping ASI Dini DengaInsiden Diare Pada Bayi 0-6 Bulan

Hasil analisa statistik dalam penelitian ini adalah bahwa hubungan antara pemberian makanan pendamping ASI dini berhubungan secara positif dengan insiden diare dan $p$ value ( $p=$ 0,001). Hasil analisa hubungan kedua variabel tersebut memiliki nilai signifikan yang dapat diterima dimana $p$ > 0,05 sehingga dapat disimpulkan bahwa hipotesa penelitian diterima, artinya bahwa pernyataan hipotesa adanya hubungan antara pemberian makanan pendamping ASI dini dengan insidensi diare dapat diterima.

Menurut Arianni (2016) di tubuh anak membutuhkan zat gizi yang sesuai untuk tumbuh dan berkembang dengan baik. Asupan zat gizi yang baik dapat diupayakan dengan memberikan ASI eksklusif sampai umur 6 bulan. Setelah itu, periode pemberian makanan pendamping Air Susu Ibu (MP-ASI). MP-ASI adalah makanan tambahan selain ASI yang diberikan pada bayi sampai usia 24 bulan, sehingga MP-ASI diberikan tepat waktu pada usia 6-12 bulan, karena pada usia tersebut 
merupakan waktu yang sangat rawan terjadi malnutrisi (Fikawati, 2015).

Lebih jauh Maharani, (2016) mengatakan bahwa pemberian makan setelah bayi berumur 6 bulan memberikan perlindungan besar dari berbagai penyakit. Hal ini disebabkan sistem imun bayi berumur kurang dari 6 bulan belum sempurna. Pemberian makanan pendamping ASI (MPASI) dini sama saja dengan membuka pintu gerbang masuknya berbagai jenis kuman.

Hasil riset terakhir dari peneliti di Indonesia menunjukkan bahwa bayi yang mendapatkan MPASI sebelum bayi berumur 6 bulan, lebih banyak terserang diare, sembelit, batuk-pilek, dan panas dibandingkan bayi yang hanya mendapat ASI eksklusif (Suryono, 2014).

Hasil penelitian peneliti menemukan beberapa hal yang berkenaan dengan pemberian makanan pendamping ASI dini, dimana mayoritas ibu memberikan makanan selain ASI kepada bayi berupa nasi tim saring yaitu sebanyak 22 orang responden (55\%), 10 orang responden (25\%) diberikan pisang/ papaya saring, dan 8 orang responden (20\%) diberikan biskuit. Dimana 27 orang ibu responden $(67,5 \%)$ beralasan memberikan makanan selain ASI pada bayi karena pekerjaan, 10 orang ibu responden $(25 \%)$ beralasan ASI tidak cukup, dan 3 orang ibu responden $(7,5 \%)$ beralasan karena bayi menangis. Mayoritas ibu menyatakan syarat pemberian makanan selain asi yaitu mudah dimakan oleh bayi $(72,5 \%)$, 9 orang ibu mengatakan makanan bersih dan sehat $(22,5 \%)$, dan hanya 2 orang ibu mengatakan banyak mengandung vitamin (5\%).

Selain itu, mayoritas ibu responden mengatakan tanda-tanda diare pada bayi yaitu tinja bayi sangat bau 29 orang $(72,5 \%)$, dan 11 orang ibu mengatakan tinja bentuknya cair $(27,5 \%) .16$ orang ibu mengatakan keadaan umum pada bayi yang mengalami diare nafsu makan bayi berkurang (40\%), 16 orang ibu mengatakan berat badan bayi menurun (40\%), 7 orang ibu mengatakan suhu tubuh meningkat/ demam $(17,5 \%)$, dan hanya 1 orang ibu mengatakan bayi gelisah dan menangis $(2,5 \%)$.

\section{KESIMPULAN DAN SARAN}

\section{Kesimpulan}

Hasil analisa statistik dalam penelitian diperoleh bahwa hubungan antara pemberian makanan pendamping ASI dini berhubungan secara positif dengan insiden diare dengan hasil $p$ value > 0,05. Sehingga dapat disimpulkan bahwa hipotesa penelitian diterima, artinya bahwa pernyataan hipotesa adanya hubungan antara pemberian makanan pendamping ASI dini dengan insidensi diare dapat diterima. 


\section{Saran}

\section{Bagi Pelayanan Kesehatan}

Bagi pelayanan kesehatan agar memberikan penyuluhan kepada ibu yang mempunyai bayi $0-6$ bulan agar tidak memberikan makanan pendamping ASI sebelum bayi berusia 6 bulan. Saran bagi ibu sendiri agar aktif mencari informasi tentang makanan pendamping ASI melalui televisi dan radio serta majalah.

\section{DAFTAR PUSTAKA}

Amin. (2015). Tatalaksanan Diare Continu Medical Education. Jakarta.

Arianni, A. P. (2016). Diare pencegahan dan pengobatannya (cetakan I). Yogyakarta: Nuha Medika.

DepKes. (2016). Diare.

Fikawati. (2015). Gizi Ibu dan Bayi. Jakarta: Raja Grafindo Persada.

Maharani, O. (2016). Pemberian Makanan Pendamping ASI Dini Berhubungan dengan Kejadian Diare pada Bayi umur $0-12$ bulan di Kecamatan Dampal Utara, Tolitoli, Sulawesi Tengah. Jurnal Ners Dan Kebidanan Indonesia. https://doi.org/10.21927/jnki.2016. 4(2).84-89

Masri. (2014). Diare penyebab kematian 4 juta Balita. Jakarta.

Notoatmodjo, S. (2012). Metodologi penelitian kesehatan (Cetakan VI) [JOUR]. Jakarta: Penerbit PT. Rineka Cipta.

Suharyono. (2015). Diare akut klinik dan laboratorium. Jakarta: Rineke Cipta.

Suryono. (2014). Bayi Sehat berkat ASI Eksklusif. Jakarta: PT Elex Komputindo.
Tamimi, M. A., Jurnalis, Y. D., \& Sulastri, D. (2016). Hubungan Pemberian ASI eksklusif dengan kejadian diare pada bayi di Wilayah Puskesmas Nanggalo Padang. Jurnal Kesehatan Andalas, 5(1), 149-153. 